ARTIGO

dO https://doi.org/10.22481/praxisedu.v16i39.6382

\title{
STUDY ABOUT THE APPRECIATION OF TEACHING FROM THE CONTINUOUS TRAINING OF TEACHERS WHO WORK IN ELEMENTARY EDUCATION IN THE PUBLIC AND PRIVATE NETWORK OF SERGIPE
}

\author{
ESTUDIO SOBRE LA VALORIZACIÓN DE LA ENSEÑANZA DE LA FORMACIÓN \\ CONTINUA DE MAESTROS EN EDUCACIÓN PRIMARIA DE LA RED PÚBLICA Y \\ PRIVADA DE SERGIPE
}

\begin{abstract}
ESTUDO ACERCA DA VALORIZAÇÃO DA DOCÊNCIA A PARTIR DA FORMAÇÃO CONTINUADA DOS PROFESSORES QUE ATUAM NO ENSINO FUNDAMENTAL DA REDE PÚBLICA E PRIVADA DE SERGIPE
\end{abstract}

Luiz Anselmo Menezes Santos Universidade Federal de Sergipe - Brasil

Sirleia Pereira Silva Gomes

Universidade Federal de Sergipe - Brasil

Jorge Luis Santana Luduvice

Universidade Federal de Sergipe - Brasil

\begin{abstract}
Resumo: A busca pela valorização do profissional docente compreende o enriquecimento de suas competências que se dá através da formação continuada, aumentando os atributos do professor em exercício bem como uma melhor qualidade de ensino no processo ensino-aprendizagem. O objetivo desse estudo foi obter um parâmetro entre os professores da rede pública e rede privada do estado de Sergipe sobre as dificuldades, impedimentos e as iniciativas pessoais para a busca da formação continuada. Para obter dados e resultados, optamos pelo método descritivo qualitativo e utilizamos como instrumento de pesquisa o questionário com perguntas objetivas e subjetivas, que alcançou sessenta docentes de ambas as redes de ensino. Os resultados apontaram que devido à falta de tempo disponível, à sobrecarga de responsabilidade, extensa jornada de trabalho, entre outros são as atuais provocações e impedimentos a superar. Os entrevistados em sua maioria apontaram que buscam por iniciativa própria atualizar-se principalmente através de palestras, cursos de capacitação, seminários, encontros, congressos e cursos de aperfeiçoamento; sendo os cursos a distância, colóquios e programas os menos procurados. As modalidades de formação continuada apontados como mais eficientes foram os cursos de aperfeiçoamento e os cursos de capacitação. É necessário, portanto a constante reflexão, a busca por novos conhecimentos e competências para melhor qualificar e valorizar o profissional docente, potencializando o ensino ao nível de qualidade na educação escolar.
\end{abstract}


Palavras Chave: Educação Continuada, Educação Básica, Ensino, Valorização Profissional

\begin{abstract}
Continuing education comprises the constant search for knowledge and training for the execution of teaching practice, and especially, it aims at reflection for the transformation of this practice, promoting the appreciation of the profession and the quality of teaching in the teaching-learning process. The purpose of this work ${ }^{1}$ was to identify and compare personal initiatives, difficulties and impediments to participation in refresher courses, among other issues of Continuing Education. As a methodology, descriptive qualitative research was applied, with the application of sixty questionnaires distributed to teachers in nine private and public schools in the State of Sergipe. We have observed that the overload of responsibilities and the long working days result in the lack of available time for a better professional preparation and teacher appreciation, making these difficulties one of the challenges to overcome in the present time. We elucidate that the majority interviewees have sought on their own initiative to update themselves mainly through lectures, training courses and seminars; as to the meetings, congresses and courses of improvement seem like a second option. Other types of continuing education such as distance courses, colloquiums and programs are the least sought after. With regard to the most efficient continuous training modalities, training courses. Therefore, it is necessary that the teacher can constantly seek to improve his profession, adding new knowledge, skills, new knowledge, new skills, always seeking for reflection on his pedagogical practice, among other elements that we characterize the appreciation of the teaching profession.
\end{abstract}

Key words: Continuing Education, Basic Education, Teaching, Professional Appreciation

Resumen: La búsqueda por la valorización del profesional docente comprende el enriquecimiento de sus competencias que se da a través de la formación continuada, aumentando los atributos del profesor en ejercicio, así como una mejor calidad de enseñanza en el proceso enseñanza-aprendizaje. El objetivo de este estudio fue obtener un parámetro entre los profesores de la red pública y red privada del estado de Sergipe sobre las dificultades, impedimentos y las iniciativas personales para la búsqueda por la formación continuada. Para obtener datos y resultados, optamos por el método descriptivo cualitativo, y utilizamos como instrumento de investigación el cuestionario con preguntas objetivas y subjetivas, que alcanzó sesenta docentes de ambas redes de enseñanza. Los resultados apuntaron que, debido a la falta de tiempo disponible, a la sobrecarga de responsabilidad, la extensa jornada de trabajo, entre otros, son las actuales provocaciones e impedimentos a qué superar. Los entrevistados en su mayoría apuntaron que buscan por iniciativa propia actualizarse principalmente a través de charlas, talleres de capacitación, seminarios, encuentros, congresos y cursos de perfeccionamiento; siendo los cursos a distancia, coloquios y programas los menos buscados. Las modalidades de formación continuada apuntadas como más eficientes fueron los cursos de perfeccionamiento y los cursos de capacitación. Es necesario, por lo tanto, la constante reflexión, la búsqueda por nuevos conocimientos y competencias para mejor calificar y valorar al profesional docente, potenciando la enseñanza al nivel de calidad en la educación escolar.

Palabras Clave: Educación Continua, Educación Básica, Enseñanza, Valorización Profesional

\title{
Introduction
}

Teacher training, without doubt, represents one of the central aspects of formal education. However, there are structural problems of society that limit this education process and

\footnotetext{
${ }^{1}$ This study was carried out with the support of the Coordination of Improvement of Higher Education Personnel - Brazil (CAPES) - Financing Code 001
} 
consequently the updating of new perspectives and resolutions of specific problems. We can see in a succinct way that the teachers went through phases of appreciation and devaluation; today we have achieved some objectives that were already rightfully ours, but there is still a long way to go so that the Education and the Education professional be appreciated as they deserve in a committed and respectful way.

According to Vagula (2007), in the traditional view on Teacher Training, the teacher is specialized in the specific knowledge of the subject under his responsibility, and his practice is little appreciated. However, today, the teacher can no longer be understood as a mere transmitter of knowledge, who carries out his pedagogical practice in a repetitive way, which translates specific and fragmented knowledge, from the scientific discourse of education sciences. We can conceive of him as a producer of knowledge, since the knowledge derived from his experience must be considered when analyzing his professional competence.

Grosch (2018) points out that the relation between teachers and knowledge is one of the main chapters in the history of the teaching profession: are teachers (and producers of their own knowledge or only transmitters and reproducers) aware of others' knowledge. Is the reference knowledge of teachers fundamentally scientific or technical? The author emphasizes that it is in the answer to these and many other questions that are found different views of the teaching profession and, therefore, contradictory projects of professional development.

It is perceptible the difference between the one who knows to teach and the one who only has mastery over contents, the one who only dominates the contents will only transmit what he knows, but in teaching there are unexpected situations that require beyond the domain, to solve problems, according to Perrenoud (2001), it is a man of situation that solves any situation, being the teacher a fundamental element in the processes that constitutes the citizen, being a priority to rethink the education of these professionals.

We admit that if, on the one hand, the teacher, as a professional, should know deeply the subject content under his responsibility and those referring to the educational sciences, on the other hand, he must improve these knowledge "by" and "in" everyday at school. Thus we are inspired by Cunha (1989), to say that the process of teacher training never ends, it is always happening; it is like a cycle that goes from the entrance of the teacher in the school, as a student until the end of its professional trajectory.

Magela (2018). The fragmentation and the combination of conceptions of pedagogical methods are one of the difficulties for teachers in the transposition of content, since many educators have no theoretical basis to differentiate the different pedagogical lines, many 
practicing the transmissive learning of the formative units. That is, theoretical paradigms are unstable and new concepts emerge, teachers must have knowledge that enable them to differentiate and use the methods according to the demand of each individual and group of students.

In Advice No. 9 (CNE/CP 9/2001, p.21) it says that without the mediation of didactic transposition, the learning and application of teaching strategies and procedures become abstract, dissociating theory and practice. Among the various challenges and difficulties encountered in teaching practice according to Perrenoud (2001) and Nóvoa (1999), they point out: an inadequate transposition of the contents of the subject so that it can be understood and assimilated by the students; individual behaviors, resistance in learning from others, uncertainty of assurance of student learning, and personal conflicts.

As for the difficulties, Oliveira (2019), points out that teachers face obstacles in order to carry out their continuing education, their pedagogical and personal plans, leaving the teacher unmotivated, the overload, pressures of the school-student-parents direction, interacting with the students because are all different, each individual has its singularity, the concern of how to reach the goals for the group of students and to act on the individual, the devaluation in the field of performance and before society.

That is why we believe that it is important to research and analyze their pedagogical practices, which needs to occur with partnership and collaboration, in order to eliminate the traditional and historical separation between theory and practice. Continuous Education, viewed from this perspective, implies the appreciation of self-training and the re-elaboration of professional knowledge by the lived practice.

We can not fail to emphasize that in relation to the qualification of teachers, at least in the Law we have had some advances. Article 67, subsection V of the Law on the Guidelines and Bases of National Education LDB (1996), refers to the period reserved for studies, planning and evaluation, included in the workload which gives the teacher conditions to update, qualify and develop in what concerns learning which is paramount in his performance as a teaching professional.

Therefore, this research proposes to answer the following question: what measures of continuous training are taken by the teachers that act in the elementary education of the public and private network for the professional appreciation and improvement of the quality of teaching? 


\section{Developments in teacher training and continuing education}

In the teaching-learning process, the teacher exerts a great influence on the student's interaction with the systematized knowledge, his/her professional skills and abilities that focuses on the process of human development and education. Faced with this, the teacher's responsibility makes it quite complex.

The teacher must be able to stimulate changes in behavior and for this must be able to perceive the different characteristics of their students, understanding and helping them to overcome difficulties in each phase of life, since this professional will be present in the various stages of the existence of the individual, thus, it is in the student-teacher relationship that humanization, dialogue and respect are established in the course of the teaching-learning process.

Each generation of children had a way of seeing their teachers. We all had teachers and we have a perennial memory not so much of what they taught us in the classroom, but how they treated us and guided us. Of his humanity and his relationship with us. Humanity, more than what they taught us. (IMBERNÓN, 2016, p. 38, our translation²).

The complexity involved in teaching work may seem like a simple task for many, but it requires greater responsibility for school education and student learning. Family participation should be decisive in this process because the school can not take this burden alone. That is, the school has lost its educational authority, requiring the intervention of the family, associations, companies, volunteers, governments, etc. "Because it is no longer possible to educate children and adolescents only at schools." (IMBERNÓN, 2016, p. 86). In this way, the quality of education does not depend solely on teachers, who are already burdened with responsibilities that the teaching profession demands.

The awareness of "what is" being a teacher like needs to be clarified enough during graduation courses and especially at the beginning of the teachers training course. That is, it is necessary that in the initial courses of teacher training, it be clarified that the processes and procedures for the education of teachers are endless due to the changes and social evolution of the new and future generations, knowledge in their daily practices must always be improved in the career. "One must realize the responsibility assumed when one defines dedication to

2 All translations have been made by the author, especially for this work. 
teaching. With or without vocation, we have a commitment to society to promote the formation of new generations "(VOLI, 1998 p.25-26).

In some papers, dissertations and books, we find that of Silker Weber (2015), in Cad. Cedes Magazine that brings his article about the debate based on the delimitations established by Law on the Guidelines and Bases of National Education (1996) and the National Plans of Education (PNE 2001-2014).

The appreciation of school education professionals, as formulated in item $\mathrm{V}$, of Article 206, in Constitutional Amendment No. 53, dated December 19, 2006, refers not only to the remuneration according to the qualification, as provided by Law No. 5.692/1971, but it includes the working conditions "[...] in the form of career plans for the public teaching profession, with a professional salary floor and admission exclusively through a public examination of tests and qualifications". In this way, the concept of teaching appreciation is broadened through the organic articulation between training, working conditions and remuneration compatible with its social recognition, organizing demands arising from the debate on education, which had as its protagonist the National Forum on Defense of Public Education. (WEBER, 2015, p. 500)

Despite the debates, discussions, agreements and disagreements among the entities responsible for the laws that regulate all those involved in the educational process, Weber (2015) emphasizes that it was within the framework of the Permanent Forum for Appreciation of the Magisterium and Quality of Education, convened in the middle of 1995 by Ministry of Education (MEC), that basic references were established for the formulation of statutes, career, salaries, teacher training, teacher appreciation and working conditions to teacher training.

The initial and continuing training of the teacher, the recognition of the pedagogical dimension of the activity-hours, the establishment of maximum number of students per classroom, the definition of the 40-hour working time as a horizon to be pursued by the state and municipal spheres, the establishment of national minimum wage. [...] Besides having an important regulatory dimension and aiming at the interdependence of the factors related to the construction of quality levels, the role of the teacher became central and its appreciation included the concentration of the working day in a single school and the receipt of appropriate remuneration through the fixation of national minimum wage. (WEBER, 2015, p. 505-507)

They are interpretations from the dialogues in the academic debate, mainly, on the connection between appreciation of the teaching profession, teacher training and quality of education. In the research by Jacomini and Penna (2016), in the magazine "Proposições" (Propositions), his article deals with the conditions of work and professional development in the teaching career and its appreciation, where they analyzed the career plans, as regards: 
training for entry into the profession; working time; incentives for continuing education and career advancement.

The professional inserted in the teaching-learning process has as an intentional activity the transmission of culturally valued elements, this professional is responsible for promoting the development of the human being in this important stage of life. But for such tasks, according to Jacomini and Penna (2016), "in order for this professional to be able to carry out such activity in schools, it is a consensus that, among other things, he has adequate training and that he is offered working conditions and professional development through his career ". (JACOMINI \& PENNA, 2016, p. 178)

The work also brings reflections about some implications and impasses regarding the overload in the workday of the teachers, such as the greater possibility of the teacher's illness and a teaching exercise that falls short of the potential of the professional, a fact that has elapsed from overwork. Faced with this, some are the negative results for the quality of teaching, according to research, which are:

Both have implications for the quality of teaching, whether over medical leave or classes that are not always well prepared or well taught as a result of teacher fatigue. It follows that among the many issues that interfere with the quality of school education is the teacher's work day. Teaching in more than one school and in different networks without an adequate number of hours for teaching support requires that the teacher, in addition to the high number of hours spent at school, work at home to prepare classes, correct work, tests, etc., thus compromising their quality of life. (JACOMINI; PENNA, 2016, p. 190-191)

With regard to continuing education, the authors emphasize that teachers must be fully integrated into a single teaching unit to facilitate access to continuing education and to invest in the value of quality education. They also warn that much is lacking to be changed, because teachers still work with lagged contracts, there is a workload overload and there are few available hours to support teachers.

Some teachers point out that they feel used to the processes of continuing education, feeling as if they are objects of research and are not respected in their interests, needs, rhythm and process, or present complaints as a dichotomy between theory and practice on the part of trainers. "The trainers, on the other hand, point to teachers' resistance, fear of change, little commitment and failure in initial training." (ALTENFELDER, 2005, p. 2)

Our experience and the educational discourse produced by educators reveal that the dichotomy between theory and practice is a recurrent and central point in the misunderstandings between trainers and teachers that end up generating 
anxieties and apprehensions in all involved. We need to dwell more on this phenomenon to understand better how and why, despite several theoretical researches and productions, the dichotomy theory and practice are maintained not only in the discourse, but in the daily school and the processes of continuous education. (ALTENFELDER, 2005, p. 3).

The author also emphasizes the importance of reflecting on the terms used to refer to the continuity of in-service teacher training, an illuminating work on the various concepts of these terms "improvement, in-service training, continuing education, retraining, or training can be equivalent terms, but are not synonyms and to differentiate them is not a semantic question, quite the contrary, because the choice of terms often reveals the positions and conceptions that guide the training actions." (ALTENFELDER, 2005, p. 3). It is important to differentiate the terms and meanings, and the most convenient in relation to the purpose of the teacher in exercise, is the term Continuing Education. Benini \& Melchior (2014) points out that despite the educational changes for improving education from LDB/96, teachers still face challenges to stay current due to:

[...] Devaluation of the teacher before the society, that is, a work without incentive, causing despair in the professional growth, which generates discouragement to new professionals to choose this area; low remuneration, which over the years has increased the withdrawal of professionals to invest in the teaching career and little appreciation by some private institutions and especially public schools .(BENINI; MELCHIOR, 2014, p. 60)

The difficulties and obstacles that occur for this search for teacher appreciation are diverse, they will occur due to the personal life of each individual, being in the double journey in the profession, other employment links different from their area of professional performance, lack of time due to personal life, both familiar and social, distorted conception and resistance as to continuing education courses, among other factors.

In a few recent studies on the challenges and difficulties in continuing education, one of the most frequent criticisms was made by teachers about continuing education processes, which is that these processes are planned without their participation.

According to the study by Alvarado-Prada, Campos Freitas, Aline Freitas (2010), the analysis of training needs as a continuous training modality involves and co-responsible teachers throughout the process of educational action, we can see that the effects have not always caused changes in teaching practice. The paper concludes that:

The construction of teacher training involves the entire trajectory of professionals, their conceptions of life, society, school, education, their interests, needs, skills and also their fears, difficulties and limitations. This 
construction of training is continuous and not restricted to an institution, to the classroom, to a certain course, since teachers can be formed through their own professional practice, starting from the analysis of their own reality and confrontations with universality of other realities that also have daily facts, political situations, experiences, conceptions, theories and other formative situations. (ALVARADO-PRADA; CAMPOS FREITAS; ALINE FREITAS, 2010, p.372)

Some teachers understand that in the courses of continuing education there is an obligatory content on the part of the institutions, when in the speech of some teachers it was mentioned that the institutions impose the updates of the teacher, as well as other forms of programs of the permanent formation. This resistance is not an isolated fact, in this perspective if teachers are accommodated and do not plan their demands to form courses based on their needs, institutions will do so in a generalized way in order to achieve and encourage the most common actions.

It is worth mentioning that obligation and duty are different concepts, since, as mentioned in LDB (1996), the teaching duties are explicitly mentioned and that the demand for professional valorization must be permanent in the career of the school educator, whether from the institutions responsible or by the attitude teacher.

Despite the various challenges that the teacher faces, it is necessary to have within him personal the constant impulse for the search of knowledge. It is necessary to understand that the knowledge of the experience is not enough, nobody becomes a teacher quickly, it is an extensive and continuous process, it does not remain stagnant in the graduation.

Concepts and paradigms concerning teacher training and continuing education are not understood by many and adequately assimilated. A concept such as professional appreciation ends up limiting its importance in the external element of the profession, which is the remuneration factor, the lack of infrastructure and recognition (the importance and representativeness of the teacher) of the society and school in which he is practicing his profession, among others.

The process of training at the higher level for educators took place in the mid-1930s in Brazil with new ideas in the field of teacher education. According to Romanowski (2013), the National Institute for Educational Studies and Research (INEP) from 1937, organized studies on educational research promoting research in the field of psychology applied to education, stimulating the inclusion of research in the education system in Brazil. Therefore, there are several surveys on the conditions and methods of teacher training and so far there is a large production of theses and dissertations that point to the need for adequating teacher training. 
The Law on the Guidelines and Bases of National Education (1996), is the general law of Education approved by the National Congress and sanctioned by the President of the Republic, under No. 9.394/96, it establishes the guidelines and bases of the national education that deals specifically with Higher Education that is found from Articles 43 to 57 of Chapter IV. In 2002, the National Curricular Guidelines for Teacher Education for Basic Education were established, whose writing focuses on the development of personal, social and professional skills of teachers.

Continuing education should be sought for a better professional development of teachers, and this search for the appreciation supported by the National Education Guidelines and Bases Law (LDB, 1996) and in the National Curricular Guidelines for Basic Education, that in order that the individual assure his universal right, the teacher should invest in their appreciation to possess knowledge in order to build, develop and apply learning methods that can cover all individuals without inequality and exclusion.

In Chapter VI, Art. 16 of the LDB (1996), it also mentions Continuing Education as collective organizational and professional dimensions, it is the rethinking of the pedagogical process, of knowledge and values, involves extension activities, study groups, pedagogic meetings, courses, programs and actions in addition to the minimum training required for the teaching profession.

Although not compulsory, continuing teacher training is bonded to the career
structure in levels, whose access is established by the combination of length
of service plus qualification titled, which makes continuing training a
requirement for salary improvement. The modalities and requirements are
differentiated for the public and private network, for basic education and for
higher education. In order for the teacher to change his methodology, he must
be willing to change, as Dewey taught. The problems and pressures of
classroom situations require the teacher to respond by changing the
procedures. These are possibilities for introducing innovations in pedagogical
practice. Changes include qualification and improvement of practice. Among
the alternatives are standardization of curricula and didactic materials; new
evaluation and planning procedures; organization of collective work projects;
greater control of the learning process; participation in the proposals to
improve school organization. (ROMANOWSKI, 2007, p. 137).

Considering Continuing Education as an integral part of the teaching work, Art. $17^{\circ} \& 1^{\circ}$, mentions that Continuing Education involves the competent institutions like the National Education Council (CNE), Higher Education Institutions (IES), Coordination for the Improvement of Higher Education Personnel (CAPES) and that are characteristics of the continuing formation of training activities, including project development, pedagogical 
innovations, among others; activities or refresher courses (aimed at improving the teacher's exercise); Extension courses; improvement courses; lato sensu specialization courses; academic or professional master's degree courses and doctoral courses among other elements that can add knowledge to the teacher.

In Chapter VII, Art. 18, \& 3. It is about the appreciation of teachers and other professionals in education, which should be understood as a constitutive and constitutional dimension of their initial and continuing education, including, among others, the guarantee of construction, collective definition and approval of career plans and salary, must have one third of the workload and other pedagogical activities inherent to the teaching profession, such as: preparation of classes, studies, research, participation in the elaboration and implementation of the Political Educational Project (PPP), guidance and follow-up for students, evaluation of students, work and pedagogic activities, meeting with parents, school council or collegiate, participation in a meeting and study or work groups, pedagogical coordination and school management, professional development activities and other activities of a similar nature and related to the school community.

The permanent updating tends to elevate and enhance teaching values, improving their knowledge, didactics, pedagogical methodology, reflection, and content transposition that is the perfect fit between theory and practice, among others. That is, they are the means through which the teacher will articulate for the best learning of the individual, contributing to the growth and development of the human being under his responsibility.

According to Shön (2000), in his book "Educando o profissional reflexivo", he argues about knowledge linked to action, which is about how to do things and reflect on it proposing in this way a new epistemology of practice. He proposes that knowledge-in-action is what "improvising" means arising from acquired competencies, it is knowledge linked to reflectionin-action and its implementation grounded, that depending on the situation one must change the practice to achieve the purpose of learning.

While reflection-in-action involves the conscious cognitive activity of the subject, it consists of thinking about what is being done on the basis of presuppositions, that improvisation is one of the variable skills, that is fundamental for the teacher to be able to vary and recombine a set of elements of a situation.

An important caveat is that in order for this to happen, you need to know what you are teaching so that you can properly lead students to learn. Shön (2000) points out that it is fundamental for the process of professional growth of the beginners, a more active follow-up 
of the professionals that educate them, helping them and supporting them to overcome the challenges that occur mainly in the initial years in which happens the transition from the graduation student to an effective teacher.

The effective search for the convergence of meaning depends on learning to become efficient in the practice of practical teaching. The instructor must learn ways of showing and saying appropriate to the peculiar qualities of the student in front of him, learning to read their particular difficulties and potentials from their efforts in the execution, as well as discovering and testing what he does in his interventions. The student should learn operative listening, reflective imitation, reflection on his own act of knowing-in-action and the instructor's meanings. (SHÖN, 2000, p. 97).

Therefore, for this practice and learning to happen according to the author, it is necessary that in teacher training courses, in addition to the internship phase, there is an interconnection between supervised teachers and experienced teachers, supervised practical-reflexive teaching.

On this aspect Nóvoa (2003) collaborates with the argument and emphasizes that:

The problem is particularly acute for young teachers, who are thrown into schools without any support, without any support from the initial training institutions or from colleagues who are already experienced. They are parachuted into school reality and wage a real 'battle of survival'. It is important to change this situation and to properly frame the initial phase of teaching, considering it as a propaedeutic and probative moment. (NÓVOA, 2003, p.3)

Teaching pedagogical practice happens as a consequence of the knowledge acquired in higher education (university) and the personal experiences acquired throughout life. When they arrive at the university, the future or the practicing teachers have a very rich and extensive background, but not always valued and resized. However, people and institutions have emerged in the states and municipalities to carry it out, taking care of the interests of government leaders without being prepared to understand its complexity, and often being administered and ministered by professionals who are not trained and without the necessary conditions to the complexity of their requirements.

Pereira Junior, Vieira (2018), Castelo Branco, Bontempo, Saraiva (2016), indicate that the curricula of the institutions that train the teacher are not satisfactory, it is observed that the higher institutions elaborate their teaching program without worrying about the issues related to professional practice, that is, theory and practice are fundamentals that must be trained in teacher education. There are several factors that interfere in the professional devaluation and 
quality of education, which impute from the higher institution, school, training, working conditions, psychic (personality, self-esteem, demotivation ...), remuneration, among others.

Regarding the question of remuneration, Gatti and Barretto (2009, p. 247) corroborate this statement by stating that "the salaries received by teachers are not so compensating, especially in relation to the tasks assigned to them. "Therefore, appreciating the teaching profession and having a decent remuneration is paramount because of the complexity of the profession."

Finally, according to Voli (1998), to educate effectively, we need educators who are able to relate to themselves by accepting their own differences and who have an essentially positive view of life and human relationships. The teacher, as an accomplished person with high selfesteem, can thus design in his students an adult model that motivates and helps to achieve a similar education, however, "one must be aware of what one should change in education. " (Vol. I. p. 236)

It is necessary and fundamental that the teacher be aware of the challenges of everyday school, that being a teacher, is an art, is to be creative, dynamic, is to have skills, is to have identity formed, character, ethics, conduct in their praxis, to things so that the student understands the meaning of life, is to be a differential and an example to be reflected in the student, because he is an influential teacher.

Therefore, with the new and recurrent educational reforms, it is up to the teacher to assume and be a professional who has duties and commitments to be performed, that despite the difficulties faced in the daily school life, it is a duty and it is necessary to add values to his profession. The expansion of values through continuing education is one of the professions and a professional ethics, it is for those who have commitment and competence to their profession, as it is responsible for teaching in the school universe interacting with the individuals in formation in this process of teaching and learning.

\section{Search methods}

Public and private schools have served as sites for collecting data on teachers' behavior patterns and what affect them directly and indirectly in view of continuing education. In this way, for this research 60 teachers were investigated who work in the elementary school of basic education in the State of Sergipe, 30 from the public network and 30 from the Private network, 
we tried to identify in the process of continuous training the elements of appreciation of these professionals in the teaching process.

All were selected without discrimination of gender and age, chosen based on the availability of the schools. For sample research we selected five public schools and four private schools. The interview script was composed of four blocks containing in each block four questions, the first block containing objective and subjective questions seeking to know the formation and the time of action in the area. The following sequences of questions were closedended questions, seeking also to know about attitudes towards continuing education, about the difficulties and impediments to refresher courses, and about the teachers' perception of professional appreciation and their future perspectives regarding profession.

Therefore, in view of the objectives of this study, which requested the trip to the countryside, where the phenomenon happens to promote the proper analysis and findings, we can characterize it as a comparative study. Because it is a specific study about the narratives of professionals from Basic Education, we understand that this is an Educational research, since it intends to clarify and describe a specific reality in the field of formal education, since it involves real perspectives of concrete subjects who build reality daily.

\section{Results and discussion}

We set out to answer, about what measures of continuous training are taken by teachers who work in public and private elementary schools for professional enhancement and improvement of teaching quality. We emphasize that the application of the questionnaires was answered by the teachers voluntarily through the informed consent form. From the questionnaires and the data obtained, we analyze the information with graphs, where we will concentrate the answers focusing on the proposed question. Graph (1).

\section{WHAT KINDS OF ESPECIALIZATION DO YOU HAVE?}

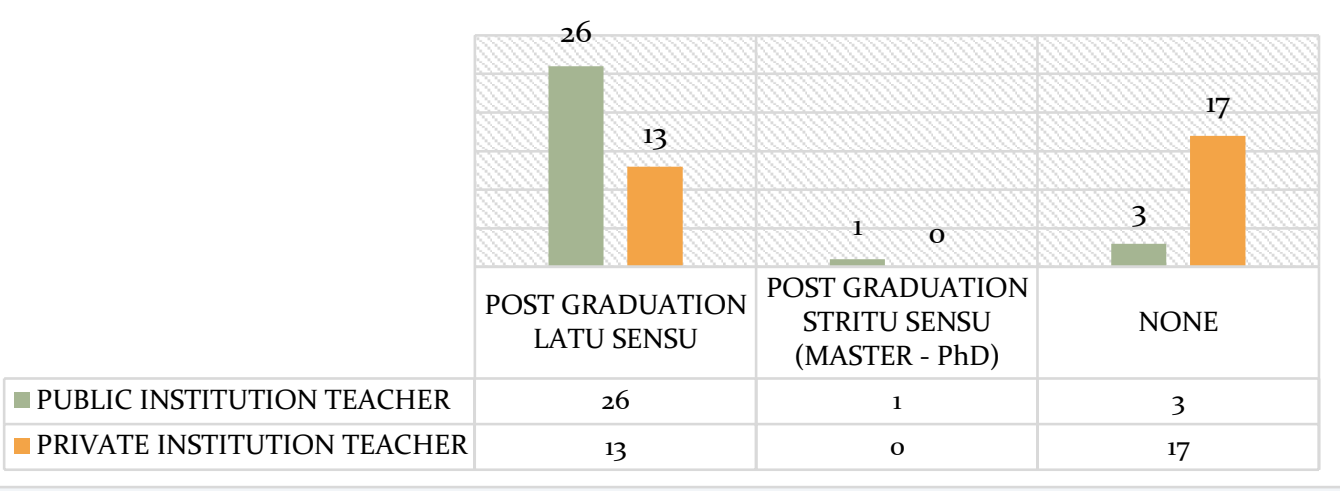


The data above allow us to obtain a parameter regarding the search for continuing education in the specialization situation, it is clear that for teachers of Public Institutions there is a greater interest in this type of continuing education, defined as one of the more prolonged activities of professional development. With this result, one can notice the greatest dedication in professional qualification for the teachers of the Public Institutions.

\begin{abstract}
Although not compulsory, continuing teacher training is linked to the career structure in levels, whose access is established by the combination of length of service plus qualification titled, which makes continuing training a requirement for salary improvement. The modalities and requirements are differentiated for the public and private network, for basic education and for higher education. (ROMANOWSKI, 2007, p. 137).
\end{abstract}

We can see, from the number of teachers with specialization in their curriculum (chart 2), that of the total of 60 surveyed, 66\% (40) teachers had initiatives to specialize. At this juncture, the teacher has in the continuing training the possibility of acquiring more specific knowledge of the profession, enabling them to meet the demands imposed by society, increasingly complex demands that overwhelm them beyond their limits, and holds them even more accountable.

The following graph (2) and (3):




The data above (2) show that of the 60 interviewed 21 teachers from both Institutions only have schedules available for continuous training on weekends, 19 teachers report that the obstacles to doing the various refresher courses is that their teaching hours at school shocks course schedules when they are offered, 14 teachers chose the option in which the institution where they teach does not offer continuing education courses for their professional updating, and of the 60 teachers, 6 report be the lack of motivation or discouragement and the lack of time due to other jobs in which they are involved.

\section{HOW MANY WORKING BONDS DO YOU HAVE WITH BASIC EDUCATION?}

- PUBLIC INSTITUTION TEACHER

$\square$ PRIVATE INSTITUTION TEACHER

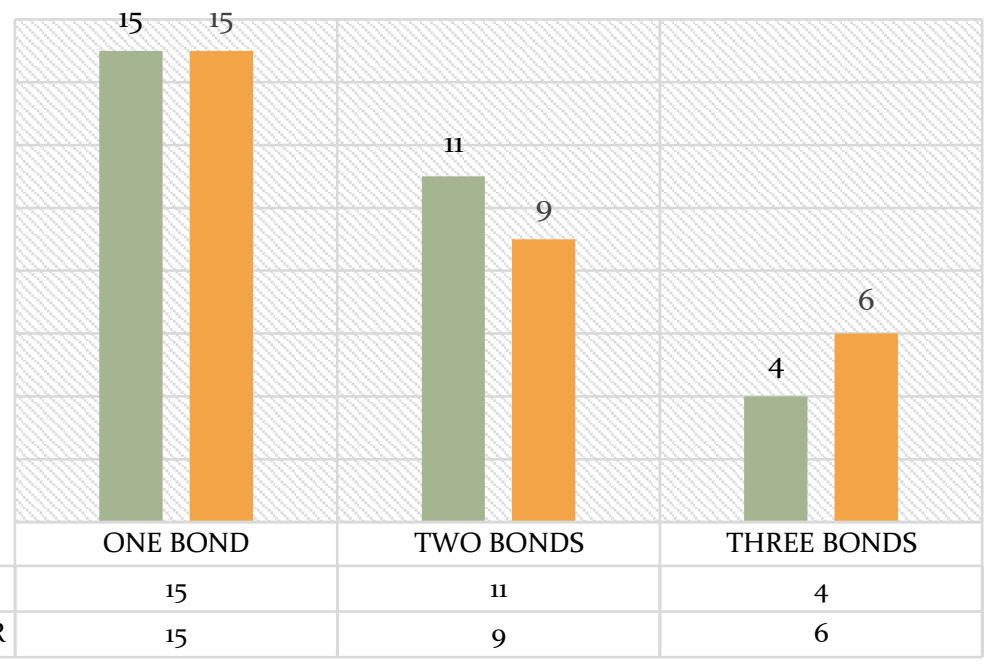

The following graphic, which will show the workload of teachers, shows that $50 \%$ of respondents say they have more than one bond with basic education.

One of the difficulties reported by teachers in the research is the lack of time available for continuing education courses, due to the need to provide family financial support, having to work in more than one school institution, among other things that we will see later. Thus, having more than one employment bond guarantees greater financial profitability, in counterpoint subtracts time and readiness towards one's professional duties as a teacher. 
Graph (4):

\section{WHAT TYPES OF CONTINUOUS TRAINING DID YOU DO BY YOUR OWN INITIATIVE IN THE LAST 5 YEARS?}

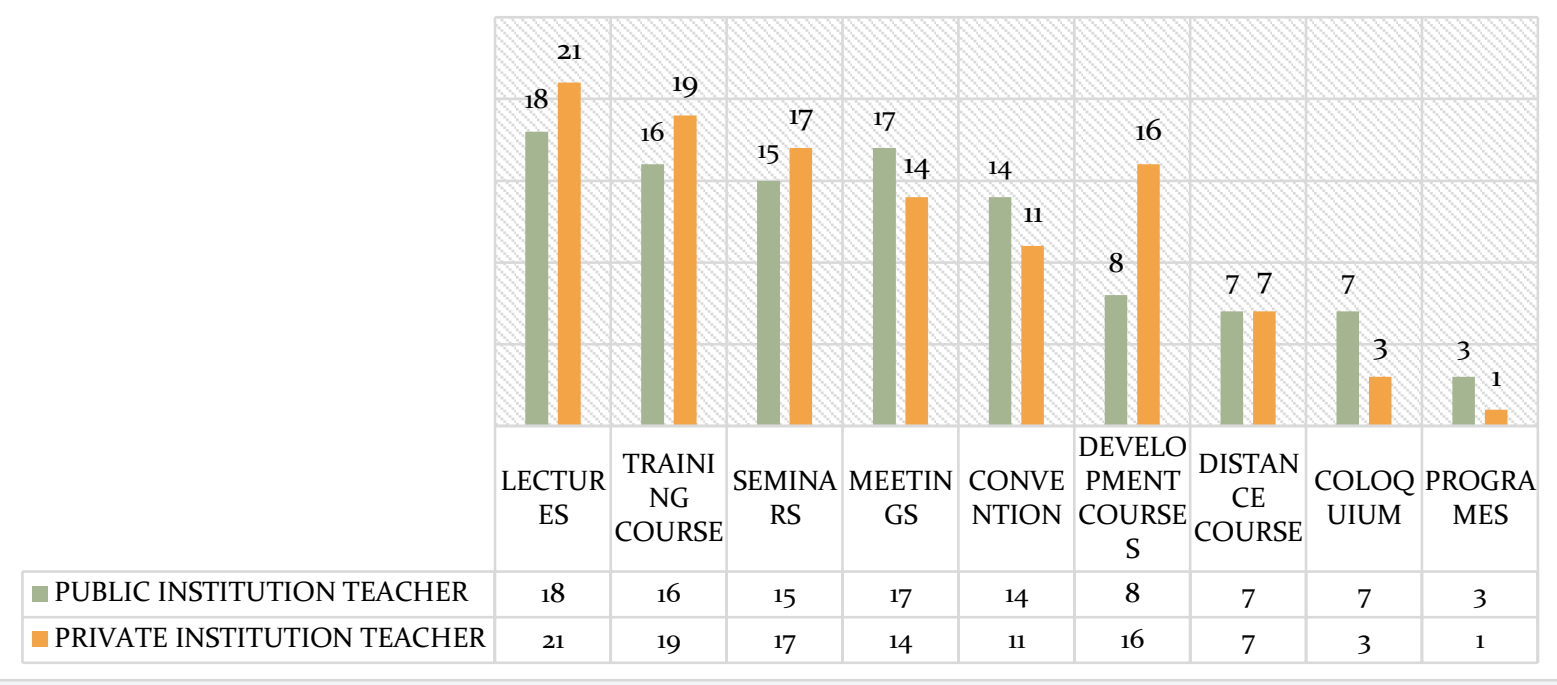

The three courses most sought after by teachers on their own initiative are lectures, training courses and seminars; followed by meetings, convention and development course; getting distance courses, colloquia and programs the last searched options. An important detail in the graph (4) is that of the 60 interviewed only 3 teachers from the Public Institution and 1 teacher from the Private Institution, they look for the programs as a continuous training course, since this type of training is more extensive than the others. It is possible that the lack of time makes it difficult for teachers to do this type of continuing education because they have a longer duration.

Graph (5):

\section{WHAT KIND OF CONTINUED TRAINING DO YOU CONSIDER TO BE MORE EFFICIENT AND PRODUCTIVE?}




In graph (5) above, we observed that among the courses considered to be most efficient by teachers, there are improvement courses with $63 \%$ preferably, followed by training courses with $60 \%$ preference. In general, from these graphs, the results show that the teachers understand the need to add values to the profession, at least once a year they look for these courses to update themselves, nevertheless, they look for courses that can have relations with the school practice, like training courses and improvement courses that indicate an association with the actions and practices applicable in their schools.

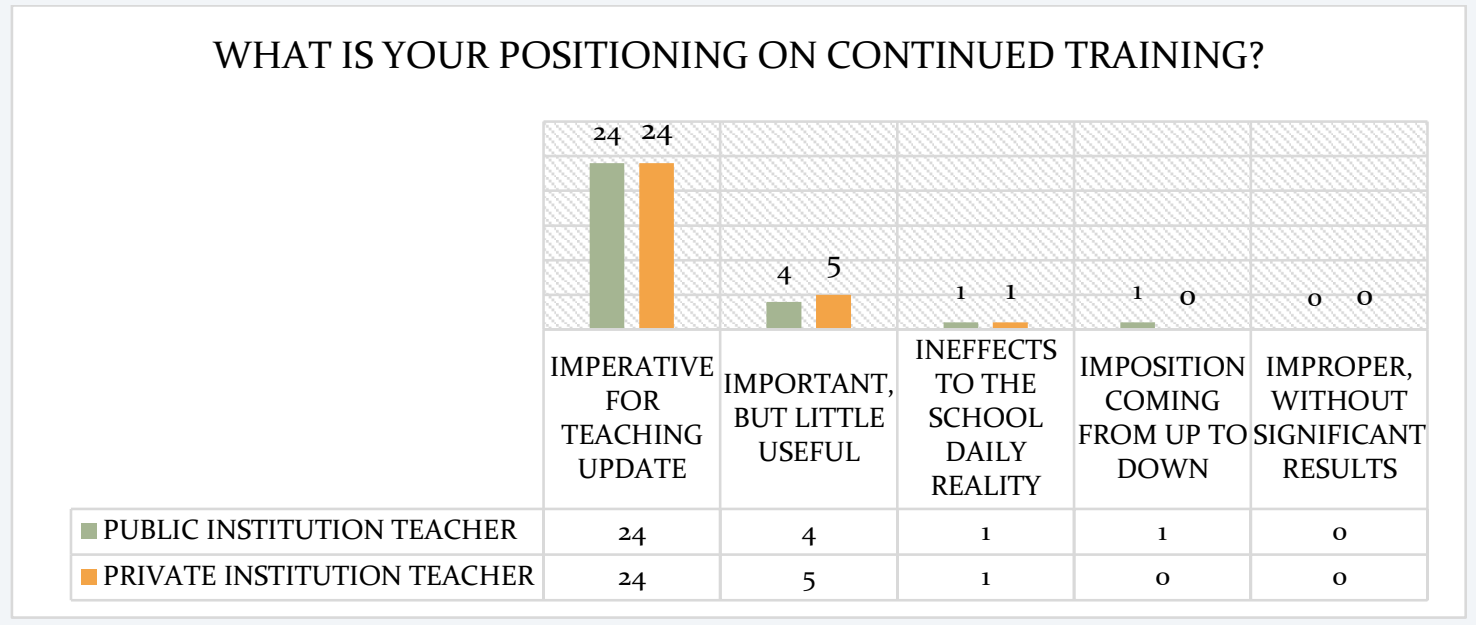

The following graphic (6), teachers between the two education networks agree that continuing education is essential for the exercise of their profession, for most, the professional update is of paramount importance for their career. Teachers are very concerned with courses that show in practice how to consolidate theory and practice, as if continuing education provided only situations with ready-made solutions, but it is not. The process of reflection that the courses of continuous education provide, does not have immediate results, but progressive and in the long term.

Reflection, by itself, is insufficient to solve educational problems; in addition, the trivialization of reflexive processes, by its simplification, promotes limitation of the epistemological identity of the processes of teacher training by limiting the teaching action to the space of the classroom. It is necessary that language value system, comprehension processes and how to define knowledge be included in teacher research on their practice. (ROMANOWSKI, 2007, P 147). 
It is necessary to reflect on the teaching activity, its ethics and conduct, to be faithful in what proposes the teaching profession. That in spite of the challenges that surround and that for many they seem like a dead end, it is the duty of the teacher the constant search for new ways, new teaching strategies to soften the nonsense in which the Brazilian education is. Thus, it is important that every teacher is aware of his duties, has an identity, and especially be aware of its meaning in the world. Its role as an educator is to foster, encourage and contribute to human development.

To be an educator is to act in the world, taking as a starting point the reality, in which one lives, its problems, its particularities and its articulations with the whole, in order to effectively construct the new possibilities of altering reality. Understanding this process is a major step for the teaching class, and that the first step is to invest in their training in a way that it is continuous.

\section{Conclusion}

The perspective regarding the valuation of the profession can be approached from various angles, since the devaluation of this class involves various aspects such as structural, politicalsocial, remunerative, quality in qualification, work overload, among others. In this work, we observe particularly the valorization of teachers from the initiative of the investigated teachers themselves, but it should be emphasized that this task is not only for teachers of Basic Education. Governors and leaders need to prioritize education in the country, investing in professional development.

As a result of this investigation it can be seen from the data obtained that the pursuit of professional updating of the teacher is fundamental to attribute improvements in the quality of teaching in the teaching-learning process, and consequently for his/her appreciation. We clarify that the interviewees of the two education networks, mostly have sought on their own initiative, seeking to update themselves mainly through lectures, training courses and seminars; Meetings, congresses and improvement courses appear as a second option. Other types of continuing education such as distance learning courses, colloquia and programs are the least sought after. Regarding the most efficient continuing education modalities, the improvement courses were followed by training courses. Congresses, meetings, distance learning courses, seminars, colloquium and lectures continue to be considered by both teachers of the two, little or less efficient. 
Regarding continuing education and teacher appreciation, which despite the difficulties in taking the courses and the need for better proposals for continuing education programs, teachers from both the private and public schools point out that continuing education is essential for the exercise of this profession.

It is necessary that the teacher can constantly seek to improve and qualify their profession, adding new knowledge, new skills, always seek reflection of their pedagogical practice, among other elements that we characterize as valuable for the teaching profession. Understanding this process is already a big step towards contributing to the valorization of the teaching class itself, and that the first step is to invest in its training, which is continuous, so that, according to Nóvoa (1999), it is the identity of a professional teacher.

This research on continuing education provided a parameter between the two education networks, their various contexts of the professional in Basic Education, from the confrontation and reflections on the real situations and conflicts of the difficulties in continuing education. Becoming a reference for the search for solutions to improve the offer of continuing education updating courses, as well as a better reflection of the pedagogical practice, teacher valorization and teaching quality.

The reality shock can trigger longings of helplessness and perplexity in situations where it does not depend solely on the teacher's dexterity. However, new knowledge will be assured as teachers seek for themselves the constant updating. Therefore, the importance of continuing education, as it contributes to acquire: better pedagogical practices; greater repertoire of knowledge to act during situations that come up at all times in the school context, due to the dynamics of relationships; efficiency in student learning dynamically and positively; a better appreciation of the profession and consequently a better quality in education, among other benefits.

It is necessary the reflection of the teaching practice, its ethics and conduct, to be faithful in what the teaching profession proposes incorporating it. Nóvoa (1999) and Perrenoud (2001) argue that despite the challenges that surround them and that many seem to have no way out, it is the teacher's duty to constantly search for new ways, new teaching strategies, because it is fundamental in teaching praxis, because Continuing education promotes the success and improvement of teaching values, enriching their knowledge, practices, perceptions, experiences and enhancing the quality of teaching, a quality that does not depend solely on teachers being already overburdened with responsibility, but that certainly, the quality of teaching depends greatly on professional quality and teaching ethics. 
Therefore, the teachers of both educational networks, private and public, indicate seeking subsidies and knowledge for the improvement of their pedagogical practice, be it short, medium or long term. It is believed that this study will be of great relevance to those who compose and analyze the educational process in Brazil and especially in the state of Sergipe, and may help in the formatting of programs focused on the teacher, taking into account the difficulties and impediments that are impasses of the search for the continuous construction of knowledge.

\section{REFERENCES}

ALTENFELDER, A. H. (2005). Desafios e tendências em formação continuada. Constr. psicopedagogia. Instituto Sedes Sapientiae, São Paulo, 2005, v. 13, n. 10.. (não possui doi).

ALVARADO-PRADA, L. E., Freitas, T. C., \& Freitas, C. A.. Continuing teacher education: some concepts, interests, needs and proposals. IN: Revista Diálogo Educacional., Curitiba, 2010, v. 10, n. 30, p. 367-387, maio/ago. doi: 10.7213/dialogo.educ.14.041.DS01

BENINI, A. L.; MELCHIOR, M.. Contexto histórico e reflexões a respeito da formação continuada de professores (p. 57-64) - In: Formação inicial e continuada na perspectiva da qualidade em educação [recurso eletrônico]/Doris Pires Vargas Bolzan, Ana Carla Hollweg Powaczuk (organizadoras). - Santa Maria, RS: UFSM, Centro de Educação, 2014. 1 e-book ISBN: 978-856112841-8

BRASIL. Lei 9.394, de 20 de dezembro de 1996. Estabelece as Diretrizes e Bases da Educação Nacional. Diário Oficial da União. Brasília, DF, v. 134, n. 248, p. 27833-841, 23 dez. 1996.

BRASIL. PARECER CNE/CP 9/2001 - HOMOLOGADO Despacho do Ministro em 17/1/2002, publicado no Diário Oficial da União de 18/1/2002, Seção 1, p. 31.

CASTELO BRANCO, Amanda Leal, BONTEMPO, Gínia Cezar, SARAIVA Ana Claudia Lopes Chequer.3A atratividade da carreira docente no Brasil: concepções de licenciados em Ciências Biológicas. Revista Tempos e Espaços em Educação, São Cristóvão, Sergipe, Brasil, v. 9, n. 20, p. 11-26, set./dez. 2016.

CUNHA, M. I. da. O professor e a sua prática. Campinas, São Paulo: Papirus, 1989 (Coleção Magistério Formação e trabalho pedagógico).

FRANCISCO, Imbernon. Qualidade de ensino e formação do professorado: uma mudança necessária. São Paulo: Cortez, 2016.

GATTI, Bernardete Angelina. BARRETO, Elba Siqueira de Sá. Professores do Brasil: impasses e desafios. Brasília: UNESCO, 2009.

GROSCH, Maria Selma. Ação humana, atividade docente e formação continuada de professores: perspectivas a partir do pensamento de Hannah Arendt. Revista Tempos e Espaços em Educação, São Cristóvão, Sergipe, Brasil, v. 11, n. 25, p. 71-82 abr.jun. 2018. 
JACOMINI, M. A., \& Penna, M. G. de O.. Carreira docente e valorização do magistério: condições de trabalho e desenvolvimento profissional. Revista Proposições, 2016 V. 27, N. 2 (80), maio/ago. doi.org/10.1590/1980-6248-2015-0022.

MAGELA, Geraldo. Formação de Formadores em Comunidade de Aprendizagem: reflexões do percurso formativo - Aprendizagem Dialógica: base para uma gestão eficaz da sala de aula. (Comunidade de aprendizagem). Disponível em:

<https://www.comunidadedeaprendizagem.com/uploads/materials/358/713ff8132a2db318705 970f7aefbe2a0.pdf> Acesso em 14 abril. 2018.

NÓVOA, António. Profissão Professor. 2ª ed. Porto: Porto Editora, 1999.

NÓVOA, António. New provisions of teachers: The school as a place of formation ; Adaptation of a conference given at the II Marist Education Congress of Salvador (Bahia, Brazil) in July 2003.Disponível em: 〈https://core.ac.uk/download/pdf/12421028.pdf〉. Acesso em: 12 mar. 2018.

OLIVEIRA, Jane Cordeiro de Formação continuada docente: avanços e dilemas na visão dos coordenadores pedagógicos. Revista Práxis Educacional, Vitória da Conquista - Bahia Brasil, v. 15, n. 34, p. 13-31, Edição Especial, 2019.

PEREIRA JUNIOR, Edmilson Antonio, Vieira, Lívia Fraga. Condições de trabalho docente: a produção acadêmica brasileira da área da educação. Revista Práxis Educacional, Vitória da Conquista - Bahia - Brasil, v. 14, n. 30, p. 247-270, out./dez. 2018.

PERRENOUD, Philippe. Ensinar: agir na urgência, decidir na incerteza. Trad. Cláudia Schilling $2^{\mathrm{a}}$ ed. Porto alegre: Artmed, 2001.

PERRENOUD, Philippe. Formação de professores profissionais: Quais estratégias? Quais competências? $2^{\mathrm{a}}$ ed. Porto Alegre: ARTMED, 2001.

ROMANOWSKI, Joana Paulin. Formação e profissionalização docente. 3 ed. rev. E atual. Curitiba: Ibpex, 2007.

ROMANOWSKI, Joana Paulin. Tendências da pesquisa em formação de professores. ATOS DE PESQUISA EM EDUCAÇÃO - PPGE/ME. Santa Catarina, v.8, n.2, p. 479-499, maio./ago. 2013.

SHÖN, Donald A. Educando o profissional reflexivo: um novo design para o ensino e a aprendizagem. (Trad.). Roberto C. Costa - Porto Alegre: Artmed, 2000.

VAGULA, Edilaine. O professor PDE e os desafios da escola pública paranaense. Londrina, Paraná: 2007 - Produção Didático-Pedagógica Volume II, Versão Online ISBN 978-85-8015-038-4 Cadernos PDE

VOLI, F.. A autoestima do professor - Manual de reflexão e ação educativa. Tradução de Yvone Maria de C. T. da Silva. 2 ed. São Paulo: Edições Loyola, 1998.

WEBER, S. O plano nacional de educação e a valorização docente: confluência do debate nacional. Caderno Cedes, Campinas, 2015 v. 35, n. 97, p. 495-515, set.-dez. DOI: 10.1590/CC0101-32622015150375 


\section{SOBRE OS AUTORES:}

\section{Luiz Anselmo Menezes Santos}

Doutor em Educação pela Universidade Federal de Sergipe. Professor Associado do Departamento de Educação Física da UFS-Brasil. Professor do Programa de Pós-Graduação em Educação da UFS. Coordenador do grupo de pesquisa Formação e Atuação de Educadores - INTERAÇÃO. E-mail: luizanselmomenezes@gmail.com

iD http://orcid.org/0000-0001-5857-9420

\section{Sirleia Pereira Silva Gomes}

Graduação em História pela Universidade Tiradentes (UNIT). Graduada em Educação Física Licenciatura na Universidade Federal de Sergipe (UFS).. Participante do Grupo de Pesquisa INTERAÇÃO - Formação e Atuação de Professores - (UFS). Ex-participante do Programa Institucional de Bolsa de Iniciação à Docência (PIBID/UFS) 2016.

E-mail: leiapsgomes@gmail.com

iD http://orcid.org/0000-0002-1117-7720

\section{Jorge Luis Santana Luduvice}

Mestrando em Educação pelo Programa de Pós-Graduação em Educação da Universidade Federal de Sergipe PPGED/UFS. Especialista em Metodologia do Ensino de Artes pela UNINTER. Licenciado em Música pela Universidade Federal de Sergipe. Professor de Artes da educação básica da rede estadual de Sergipe. Professor de música do Conservatório de Música de Sergipe. Integrante do grupo de pesquisa Formação e Atuação de Educadores INTERAÇÃO-UFS. E-mail: jorginho.luduvice@ymail.com

iD http://orcid.org/0000-0002-0183-5937 